$\stackrel{W}{=}$

Global burnals Inc.

है

\title{
Embodied Mind and Neural Underpinnings of the Aesthetic Experience. A Case Study from the German Eighteenth Century: 4E Cognition Theories Forecasted by Johann Gottfried Herder
}

By Renata Gambino \& Grazia Pulvirenti

University of Catania

Abstract- Recent theories within the avenue of the bio-cultural turn, and particularly about embodied cognition are forecasted in the anthropological, philosophical, physiological and scientific debate of the late 18th century in Germany. Philosopher and theologian Johann Gottfried Herder contributed to this discourse sigificantly, opening up new perspectives on the link among thought and language and body. In this paper we aim at highlighting some core issues of Herders's discourse about knowledge, perception and cognition, that seem to anticipate some of the most recent $4 E$ Cognition issues.

Keywords: Embodiment, embodied cognition, anthropology, knowledge, neuroscience.

GJMR-A Classification: NLMC Code: WL 340

Strictly as per the compliance and regulations of:

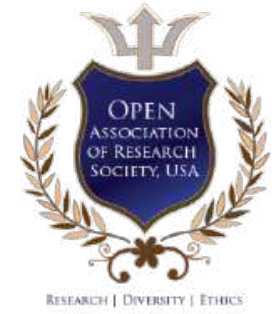

(C) 2021. Renata Gambino \& Grazia Pulvirenti. This is a research/review paper, distributed under the terms of the Creative Commons Attribution-Noncommercial 3.0 Unported License http://creativecommons.org/licenses/by-nc/3.0/), permitting all noncommercial use, distribution, and reproduction in any medium, provided the original work is properly cited. 


\title{
Embodied Mind and Neural Underpinnings of the Aesthetic Experience. A Case Study from the German Eighteenth Century: 4E Cognition Theories Forecasted by Johann Gottfried Herder
}

\author{
Renata Gambino ${ }^{\alpha}$ \& Grazia Pulvirenti $^{\sigma}$
}

\begin{abstract}
Recent theories within the avenue of the bio-cultural turn, and particularly about embodied cognition are forecasted in the anthropological, philosophical, physiological and scientific debate of the late 18th century in Germany. Philosopher and theologian Johann Gottfried Herder contributed to this discourse sigificantly, opening up new perspectives on the link among thought and language and body. In this paper we aim at highlighting some core issues of Herders's discourse about knowledge, perception and cognition, that seem to anticipate some of the most recent $4 E$ Cognition issues.
\end{abstract}

Keywords: Embodiment, embodied cognition, anthropology, knowledge, neuroscience.

\section{INTRODUCTION}

ohann Gottfried Herder is considered a key figure in the German culture of the Aufklärung for his wellknown merits as philosopher, anthropologist, theorist of aesthetics and poetry, but surprisingly enough some of his theories have become subject of renewed interest by current philosophical and scientific discussions about human mind and cognition. In particular, growing attention for his works has aroused in the transdisciplinary field of biocultural anthropology and in cognitive research (see: Alert; Waldow \& DeSouza; Gaier; Weiler). Whereby several recent studies reinterpreted Herder's theory of knowledge, his philosophical anthropology, his reflections on the origin of language, on aesthetic perception, and on empathy as deeply innovative and overcoming the medical, anthropological and aesthetic discourse of his time (see Sauder, Sinnliche 137-153). Indeed, Herder played a crucial role in examining some mental and cognitive processes underlying the aesthetic production and reception: he deeply reflected about the unity of the mind-body system in any knowledge process, i.e. he considered it as depending from the interaction between the physiological dimension. Linking philosophy, anthropology, ethnography and history, he laid the foundations not only for the constitution of the cultural sciences, but also for the cognitive ones. His work, which was partly overshadowed by the prevailing

Author a $\sigma$ : Department of Human Studies, University of Catania, Research Centre NewHums - Neurocognitive and Human Studies. e-mail:grapulvir@gmail.com
Kantian vision, is now re-evaluated by recent studies, which consider it profoundly innovative and precursor of modern cognitive issues:

Herder is very much a thinker of our time. Instead of approaching facets of human existence in an isolated fashion, he brings the entire human being into focus by tracing its connection with the natural, cultural and historical world. [...] Herder's Anthropology resonates with many demands and needs arising today, when national and cultural interests - and conflicts - take on new, and old, forms in the wave of unprecedent global changes. (Waldow and DeSouza, Introduction 219).

In a recent book with the title Herder: From Cognition to Cultural Science, we find the work of the thinker revisited in a transdisciplinary perspective, which highlights the polyphony of Herder's innovative approaches to the philosophy of history, language, ethnography, poetry and, in particular, to his definition of the cognitive processes as embodied processes, i.e. rooted in bodily and sensory perception. The transdisciplinary dimension of Herder's research leads to the elaboration of an intimately organic vision of knowledge rooted both in the human bodily perceptual dimension and in history. This has been highlighted by various studies, that point out how "[...] history itself is to be considered as connected to an organicmorphological genetic research [...]" (Marelli 13), which is part of "[...] a theoretical reflection on the arts, starting from the specificity of sensorial experiences [...]" (Marelli 13), and reaching out to "[...] a re-foundation of philosophy as a science focused primarily on the human being and committed to safeguarding and harmonizing all his faculties, expressions and developments" (Marelli, 14).

This brings us back to the definition of "embodied mind", which finds an articulated theorization also in Herder's work, obviously expressed in the language of his time. He, therefore, created the epistemological framework for a humanism, that places the individual at the centre of a complex biological and cultural system, determining the subject and determined by him in turn: 
At the heart of this anthropology is a conception of human beings as primarily sensible animals whose unique linguistic and rational capacities are constitutively shaped by their historic-cultural circumstances, which they reproduce and shape in turn. Herder grounds this conception in both a naturalistic account of human development and a metaphysics and epistemology of which soul-body interaction is a central feature. This conception forms the basis of Herder's challenge to, and reinterpretation of, well-established conceptual distinctions, such as those between nature and culture, animal and human, reason and sensibility. (Waldow and DeSouza 259-265).

The fundaments of the philosophical thought of the Aufklärung are re-elaborated by Herder in terms of a new epistemological framework referring to a conception of knowledge as a dynamic and rhizomatic phenomenon: "[...] [Herder's] philosophy is at its best [...] when it learns from and enters into an ongoing conversation with disciplines such as history, political science, anthropology, medicine, and biology." (Gjesdal 3).

Within this vision of knowledge, Herder highlights the profound interconnection among biological existence, mind cognitive processes, knowledge and artistic creation, building a vision of the body-mind unity which, in our opinion, anticipates the theories on embodiment put out by recent cognitive sciences, starting from Humberto Maturana and Francisco Varela (see Maturana and Varela, Autopoiesis), further developed by Vittorio Gallese (see Gallese, Embodied 2018, 31-46; Problem 70-79; Naturalizing 50-59; Empathic; Arte 49-67; Corpo 8-24; Motor 486-498; Before 659-669; Finding; Embodied 2004, 23-48) and newly giving rise to the heuristic framework of $4 E$ Cognition (see for further discussion Newen et al). This last heuristic frame regards the functioning of the human mind not in terms of the representational and computational model of firstgeneration cognitive sciences, but relating it to the physical dimension of the body interacting with the environment: the human mind is therefore considered as 'embodied', rooted in corporeity ('embedded'), 'enacted' and 'extended' (see Newen et al). This perspective is considered crucial within the bio-cultural turn (see Wojciehowski and Gallese) for its multiple implications in the field of aesthetics and reception of the arts.

Herder's reflection moves from a unitary biological vision of the human being: he starts from the inquiry about human perceptions and sensations, through which the subject opens up to the world, i.e. the body creates his/her own vision of the world, aimed at a knowledge that has as its supreme goal in the "best for the community" ("zum Besten des Volkes") (Herder, Philosophie 122). Therefore, many further core concepts of Herder's theories, like his conception of language, move from a biological vision of the human being, considering physiological sensitivity, perception and impulses in their interaction with the environment as essential engines of the faculty of thought, speech and consciousness, placing language as a priority over the formation of consciousness. Herder sets the basis for a science that not only reaffirms the unified vision of the human being, but also aims to advance mankind's evolution and the perfectibility of the humankind (Beförderung der Humanität).

In order to highlight how some of the pivots of Herder's thought constitute an anticipation of the theories on embodiment, we will first briefly present the core ideas of the embodiment theories and of the four key concepts of the $4 E$ Cognition, referring these last to the relative corresponding precursor concepts theorized and discussed by Herder; further we will relate Herder's concepts to the current epistemological frame.

\section{il. Embodiment in Neurocognitive THEORIES}

The interaction of body, mind, and environment is at the core of the embodied mind theory, according to which every mental act is rooted in the body, influenced by it, and in turn determined by it. This heuristic frame has had a significant impact on the anthropological, philosophical, and aesthetic discourse about the human being and its production, giving rise to new transdisciplinary fields of research such as neuroaesthetics and neurohermeneutic, which investigate the artwork as a product of the fundamental faculties of the mind, sheding new light on phenomena such as empathy, immersion and, in general, literary and aesthetic reception (see Gambino and Pulvirenti 2019). More specifically, the concepts of embodiment and embodied mind refer to the physiological and biological mind-body unity as a premise for every form of subjectivity, consciousness, thought, artistic production and social interaction. The term embodied cognition enables us to overcome the nature/culture dichotomy, referring to cognitive processes considered in biological terms as dependent on the interaction among mind, body and environment. Such theories have profound implications in the study of complex phenomena, such as thought, emotion, perception, language, conscious feeling of the Self, understood as an entity capable of feeling, remembering and narrating its experience in the world (see Damasio for further discussion).

Within this field of research, specific phenomena have been focused on, such as those of intercorporeality, intersubjectivity and embodied simulation, investigated particularly by Gallese (see Gallese and Cuccio), who takes up, as far as intersubjectivity is concerned, the concept developed by Husserl in Ideas for a Pure Phenomenology, and in Cartesian Meditations, further inquired by other 
phenomenologists (such as Max Scheler, Edith Stein) and, more recently, by Dan Zahavi.

In Gallese's theories the concepts of intercorporeality and intersubjectivity refer to neuroscientific acquisitions such as those about mirror neurons, highly significant in transdisciplinary investigation. The concept of embodied simulation (see Gallese et al., Rizzolatti and Sinigaglia) is a cue issue for understanding the processes of aesthetic reception. According to its main assumptions, an observed action gives rise in the observer to a process of imitative replication within a mental simulation, which is based on the activation of the sensorimotor cortex. The principle of embodied simulation is fundamental for the immediate understanding of actions and emotions of others, since it constitutes a direct, pre-reflexive and pre-conceptual access to actions, emotions, thoughts and behaviors of others. This happens on the basis of the motor simulation, which is part of the phenomenon studied and defined by Gallese as motor cognition (see Gallese): cognitive abilities, such as the identification of motor aims in the behavior of others, as well as the anticipation of an action, are possible on the basis of the functional architecture of the motor system, which in turn is organized into motor acts with specific aims. In fact, there is a close anatomical and functional relationship between action and semantics, i.e. a sensorimotor integration between the action of the subject in relation to an object and its meaning. Some cerebral areas (among these the frontal, parietal and temporal ones) produce a 'copy' of each motor scheme used to perform actions in the world coding it on the base of the 'goal of that action' (i.e. taking, pushing, pulling, etc.) (see Gallese et al.). Therefore, in Gallese's view, the brain operates through a prelinguistic understanding of a motor-pragmatic nature. This 'motor language' is shared by all human beings (intercorporeality), who are thus able to immediately understand the purpose of the motor acts of others (intersubjectivity) (see Gallese and lacoboni for further discussion). Such processes are activated not only by witnessing to an action performed by others, but also by imagining a motor act. This allows the human being to understand and anticipate the purpose of a perceived action. This motor language is constantly active, both in the understanding of an observed action and in the relationship that has to be established with the objects of the world. On its turn, this pre-linguistic dynamic feature of human communication allows to create a positive and functional relationship with the world and with others, allowing us to be social creatures (Cuccio et al. 69; Rizzolatti and Sinigaglia, So 4).

The processes of embodied simulation and the shared motor language are at the origin of the phenomenon of empathy, by which we mean the "ability to imagine oneself instead of others and understand the feelings of others" (lacoboni, Existential 310). This ability allows human beings to understand actions and situations referring to a mimetic principle, by mirroring what is perceived in one's mind and body (Gallese, Io 38). Empirical studies suggest that imitation plays a fundamental role in empathic feelings: in order to understand not only the actions, but also the emotional states of others, human beings activate the same neural systems involved in the expression of the emotions of others as if they were personally experiencing it. Moreover, empirical studies suggest a correspondence between the phenomenon of empathy and the existence of a 'mirror system' at the neural level, capable of encoding both transitive and intransitive motor acts and their sequence of movements, 'firing' also in case of mimed actions (see the groundbreaking studies of Gallese, Rizzolatti and the team of Parma, about mirror neurons and premotor cortex).

The complex embodied processes imply a sort of emotional and cognitive visceral motor resonance, determining an understanding of the emotions and sensations felt by others on the basis of an intentional consonance, in which the subject 'puts himself in the place' of another, maintaining his own otherness. On the basis of this hypothesis empathy turns out to be the result of unintentional associations between one's own body and that of others, or between one's own body and the bodies of characters in a fictional world, since the same simulation mechanism allows the reader to access the emotions of real and fictional characters in a second-person perspective relating what happens to one's own experience (see Gallese for further discussion).

Surprisingly enough, many of these concepts have been forecasted and formulated in eighteenthcentury terminology by Herder. Before explaining the fundamental issues of his theory, we will briefly discuss the main aspects of embodiment theories by classifying them according to the categories of the most recent researches on embodied cognition, i.e. the qualities of the mind as: a) embodied, b) embedded, c) enacted, d) extended, referring to the corresponding principles of Herder's theorization, which we will deal with further on.

a) Embodied Mind (in Herder: Commercium mentis et corporis, Nervengebäude / "Nervous system", Reize / Stimuli, Sinne / Senses)

The linkage among physiological, mental and cognitive processes, summarized in the concept of embodied mind, was revolutionary highlighted by Humberto Maturana and Francisco Varela in their studies Autopoiesis $(1980,1985)$ and The Tree of Knowledge (1987). In these works, the two scientists investigated the embodied mechanisms of creation, self-regulation and cognition of living beings from a biological perspective. Synthesizing the complex theories of Maturana and Varela, life on earth is regulated by a process of autopoiesis, according to 
which each living unit self-regulates itself, maintaining its own identity through its actions, i.e the organization of the system defines its features and its identity. Being, acting and knowing coincide within the autopoietic organization, i.e a network of continuous dynamic interactions among the molecular components of each cellular unit, produced through metabolic dynamics as distinct elements, but all interacting within the surrounding environment (see Varela et al. for detailed studies) (see in Herder the ideas about the Ganzer Mensch / whole man, the commercium mentis et corporis). Multi-cellular living beings are characterized by their sensory and motor components and their dynamic modes of relation in the nervous system, whose architecture is universal, but whose complexity and breadth change in the various living beings. According to Varela and Thompson, active and bodily relationships are part of the double embodiment of the mind in the body and of the body in the environment (see in Herder the concepts: Nervengebäude, Reize, Sinne):

By using the term embodied we intend to highlight two essential issues: 1) cognition depends on the experience gained from having a body with different sensorimotor capacities; 2) these individual and subjective sensorimotor capacities are in turn embodied in a wider context of biological, psychological and cultural nature. (Varela et al., Embodied 172-73).

Other scholars, including Johnson and Rohrer, referring to James and Dewey's pragmatism, and especially to the principle of continuity postulated by the latter, have theorized the absence of ontological differences between biological functions and higher brain functions resulting from organic levels:

In explaining the very complex 'higher' functions, such as introspection or language, we do not refer to new ontological entities, new dynamics or new processes, but only to natural ones. More complex levels of organic functions are just that: levels, nothing else, emerging properties of 'superior' functioning [...]. According to this assumption of continuity, every dynamic of the mind, and even the faculties of reasoning and abstract conceptualization, must be rooted in the organic faculties of perception, sensation, manipulation of objects and bodily motion. Social and cultural forces operate, in turn, to develop these faculties, including language and symbolic reasoning, until they reach their maximum potential. (Johnson and Rohrer 21).

The emotional dimension (about which Herder, as we shall see, has surprising insights in relation to the bodily nature of the Empfindung) is also an embodied phenomenon, which participates in thought. Deacon (Deacon 37), to mention just one example, states that emotion is not distinct from cognition and cannot be dissociated from it, since it plays a central role in knowledge through art. This involves the manipulation of emotional experiences integrated into complex phenomena that determine the emergence of new concepts and ideas.

\section{b) Embedded Mind (in Herder: Analogon, Unity of the existing)}

The nervous system, according to many scholars including Colombetti and Thompson, acts by developing "coherent configurations of meaning" (Colombetti and Thompson 85) that vary according to different contexts. As a result, the human being, intended as an autonomous system, does not passively receive information from the environment but in relation to it. Cognition is therefore an embodied emergent process based on perception and action of an autonomous and self-organized organism that produces meaning inside and outside itself (see in Herder the concept of narration and of cognition elaborated in Erkenenn und Empfinden der menschlichen Seele). The two poles of this dynamic process are the mental embodied activity of the subject and the environment; the latter is configured as a "domain of relations produced by the autonomous activity of the cognitive being and by the way it is coupled to its environment" (Colombetti and Thompson 85):

[...] to say that cognition is embodied means that it arises from its embodied interactions with the environment. Starting from this perspective we can say that cognition depends on the type of experience resulting from having a body with specific perceptive and motor abilities, inseparably linked togheter, and that all together constitute the matrix within which the faculties of reason, memory, emotion, language and all the other faculties of mental life are woven. (Thelen et al., Dynamics 1).

c) Enacted Mind - Cognition (in Herder: Erkennen und Empfinden / Cognition and Sensation, "Erkenntnis und Empfindung leben nur in Tat" / Cognition and sensation live only in action)

In order to investigate the complex phenomenon of cognition, we need to consider the interaction between each individual brain-body system and that of others: "To make sense of cognition we need to study the brain, the body, their relationship with the world and with the brain-body systems of others" (Gallese, Embodied 31). Cognition is considered as a form of experience of the body in the world: knowledge is no longer understood only as representational, i.e. in the context of formal operations of abstract symbols, but as enaction (Thompson, Mind; Empathy 1-32; see also Noë, Vision), i.e. as an action generated within the organism in the process of its relation with the world, culminating in the creation of a complex system of actions, interactions and meanings. Perception, experience and cognition arise from the relations created between the mind, embodied in the whole organism, and the environment in which the body is located and with which it interacts. Therefore, a basic phenomenon, such as perception, does not occur 
passively: it is the result of an 'activity' that changes the status of the nervous system during the experience of the world (see Thompson and Noë for further discussion). In this perspective, cognition is to be understood as the action of the living organism in its interaction with the environment. Cognition appears therefore as an active phenomenon, distributed in the body, related to the neural and sensorimotor specificities of the subject, that is immersed in a wider biological context. Living itself is understood as a process of continuous cognition: "Living systems are cognitive systems and living is a process of cognition" (Maturana and Varela, Autopoiesis 59). The interaction of the subject with the environment is perceived actively and elaborated as lived experience, stored knowledge, emotions, memories (see in Herder: Apperzeption, Bewußtsein/Apperception, Consciousness). The cognitive reorganization of the lived experience induces a transformation of the organism and its autopoietic reorganization by means of enaction:

Cognition no longer appears to be a problem-solving activity, carried out on the basis of representations; rather, it takes place as an enactment, namely through the development of a world in a possible narration by connecting structural meanings (Varela et al., Embodied 205).

This implies that all phenomena related to enaction, such as language, sociality and culture, depend on corporeity: "Cognition is based on the fact that we are in a world which is inseparable from our bodies, our language and our social history - in short, from our embodiment" (Varela et al., Embodied 149).

d) Extended Mind (in Herder: Treatise on the Origin of Language, "Würkungskreis" / Circle of activities)

Since the Nineties of the last century, the concept of the embodied mind was combined with that of the extended mind and used to indicate that mental processes do not reside only in the brain-body activity but they are extended to artifacts and social configurations modifying the mind-body skills and knowledge (see Newen et al. for further discussion). In the perspective of embodiment, language is regarded as the result of an interaction among organisms, while the wide field of cultural phenomena is considered as the result of a "transgenerational stability of behavioral configurations ontogenetically acquired within the dynamics of communication in a social environment" (Maturana and Varela, Albero 170). The 'simulative theory' of language, already hypothesized by Varela, has been recently scientifically confirmed: the linguistic activity is related to the activation of brain areas used for perception and movements (see Faschilli). The simulative mechanisms are obviously anchored in our corporeity (see Gallese and Lakoff), in a "model of bodily representation" (Cuccio et al. 70). When we read or listen to sentences that indicate actions, a process of simulation of those actions takes place in our brain, since language implies the activation of our motor system (Gallese and Cuccio 11). Therefore, Gallese concludes that "reading or listening to a sentence describing an action performed by a hand activates the motor representation of the same action" (Gallese and Cuccio 11). This motor activation can also take place in the case of abstract language or of a figurative use of language, as in case of metaphors: "The enaction of the simulation process in linguistic understanding suggests that the symbolic dimension and the body dimension co-exist in the linguistic practice" (Gallese and Cuccio 16). Not only the sensory and motor activations are fundamental to linguistic comprehension, but they are also active in the elaboration that language makes of aspects of our most complex bodily experience, both in terms of subjective experience and of its conceptualization. (GP)

\section{ili. Herder, the Precursor}

Before investigating the specific issues of Herder's thought revealing him as a precursor of embodiment, it is necessary to briefly highlight Herder's knowledge in physiology and medicine. Herder's interest in the physiological and anatomical theories of the physician Franz Joseph Gall, considered together with Samuel Thomas von Sömmerring and Johann Christian Reil the founder of the neurological anatomy in Germany, is well known. As his wife Karoline put out in Erinnerungen aus dem Leben Joh. Gottfrieds von Herder: "[Herder] sehnte sich, diesen Mann [Gall] selbst zu sehen, und mit ihm über seine Bemerkungen und Schlüsse zu sprechen, da sie in die feinsten organischen Gesetze der menschlichen Natur einschlagen" [[Herder] longed to meet this man [Gall], and to talk to him about his remarks and conclusions, as they illuminate the finest organic laws of human nature] (Müller 109; see also Gall's works).

Herder took fundamental inspiration from Gall's works about the anatomy of the human body (Häfner 390), as well as from Johann Wilhelm Ritter's theories about the principles of galvanism and electricity, and from Abraham Gottlob Werner's ideas about geology. However, as Häfner points out (Häfner 390), the specific sources for the study of the physiology of the brain, which flow into his anthropology, cannot be specified, while his theories reveal the influence of the physiology of Albrecht von Haller (Häfner 394) and of Charles Bonnet, specifically in relation to the physiological bases of psychology. This is demonstrated also by the presence in his library of the following volumes: Essai analytique, Considérations sur les corps organisés (1762), Contemplation de la Nature (1764) and Palingénésie philosophique (1769) (see Häfner). The reception of texts by Bonnet highlighted by Häfner build up the premises for a theory of history understood as an 
expression of human action based on the dispositions of the corporeal organism.

More specifically, we will now see Herder's main contributions to the new definition of the paradigms of embodied mind and cognition, rooted in the principle of the interaction of bodies in the totality of the existing. In order to draw the parallels with the recent theories on embodiment clearer, we will proceed by indicating the references to the different core theories of $4 E$ Cognition, referring to their presentation in the previous paragraph:

a) Commercium mentis et corporis, Nervengebäude / Nervous system, Reize / stimuli, Sinne / senses (Embodied Mind)

The bodily dimension, which determines for Herder the definition of the human being as " $\alpha \nu \theta \rho \omega \pi$ s

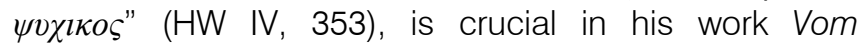
Erkennen und Empfinden der menschlichen Seele. Starting from the title, Herder puts sensory cognition, thought and emotion in relation, rooting them in corporeity, i.e. in what he defines the Nervengebäude [nervous system], understood as a physiological totality from which thought, will and spirit derive, and which are constantly interacting with the surrounding world:

[...] das Nervengebäude [...] dadurch der Schöpfer die innere und äußere Welt, und in uns Herz und Kopf, Denken und Wollen, Sinne und alle Glieder knüpfet. Würklich ein solches Medium der Empfindung für den geistigen Menschen, als es das Licht fürs Auge, der Schall fürs Ohr von außen sein konnte.

[[...] the nervous system [...] through which the creator builds both the inner and outer world, and within us heart and head, thought and will, senses and all bodily parts. This is a remarkable medium of sensations for the human being, as it is the light for the eye, the sound for the ear.] (HW IV, 351).

Sensory perception is conveyed by stimuli called "Reize" [stimuli] and occurs through the senses, which are therefore understood as instrument of thought, just as in the current concept introduced by Varela (see paragraph: Embodied mind): "[...] ohne Körper ist unsre Seele im Gebrauch nichts: mit gelähmten Sinnen ist sie selbst gelähmt [...]" [[...] without a body our soul is nothing: with paralysed senses it is paralysed itself [...] (HW IX/2, 120).

For Herder there is a circularity among outer world (Welt), brain (Hirn), heart (Herz), from which image and passions originate. The senses, from which images and sounds of the world derive, are pervaded by a force that unifies everything, postulating an absence of ontological difference between biological and mental functions. This force is defined by Herder as "Äther" [ether]: this principle is not external to the body, but has the same nature, which gives rise to the creation of thought, starting from a stimulus that can be internal or external to the body:
Wir empfinden nur, was unsre Nerven uns geben; darnach und daraus können wir auch nur denken. Nenne man nun diesen lebendigen Geist, der uns durchwallet, Flamme oder Äther; genug, er ist das unbegreifliche himmlische Wesen, das Alles zu mir bringt und in mir einet. Was hat der Gegenstand, den ich sehe, mit meinem Hirn, das Hirn mit meinem wallenden Herzen gemein, daß jenes Bild, daß dies Leidenschaft werde? Siehe da ist ein Etwas, das von sonderbarer Natur sein muß, weil es so sonderbaren Verschiedenheiten dienet. Das Licht konnte nur Eins, den ganzen dunkeln Abgrund der Welt zum Bilde machen, dem Auge alles veräugen: der Schall konnte nur Eins, hörbar machen, was sonst nur für andre Sinne da wäre. So weiter. Dieser innere Äther muß nicht Licht, Schall, Duft sein, aber er muß alles empfangen und in sich verwandeln können. Er kann dem Kopfe Licht, dem Herzen Reiz werden: er muß also ihrer Natur sein, oder zunächst an sie grenzen. Ein Gedanke, und Flammenstrom gießt sich vom Kopf zum Herzen. Ein Reiz, eine Empfindung und es blitzt Gedanke, es wird Wille, Entwurf, Tat, Handlung: alles durch Einen und denselben Boten.

[We only feel what our nerves give us; we can only think about them and from them. Let us call this living spirit that wanders through us flame or ether; well, it is the incomprehensible ethereal being that brings everything to me and unites it within me. What does the object I see have in common with my brain, the brain with my flowing heart, that becomes image and passion? Behold, there is something which must be of a strange nature, because it serves such strange diversities. The light could only make one thing, bring the whole dark abyss of the world into an image, taking it to the eye; the sound could only make one thing audible, which otherwise would only be there for other senses. And so on. This inner ether does not have to be light, sound, fragrance, but it must be able to receive everything and transform it into itself. It can become light to the head, a stimulus to the heart: it must be their nature or must first border on it. One thought, and a stream of flames pours from the head to the heart. A stimulus, a sensation and it becomes thought, will, design, action, deed: all through one and the same medium.] (HW IV, 352).

Carring out his reflection through the technique of paradox and referring to the studies conducted at the time by Diderot and others concerning blind individuals, Herder bases the whole philosophy on the physiology of the body: a blind person would have an excellent philosophical mind, since the other senses would be heightened by the lack of sight. Such a deprivation would lead to a strengthening of bodily perception and to a healthy and powerful philosophical thought because it would be nourished not by abstraction, but by sensory concreteness:

Hier würde eine Physiologie der Seele und des Körpers kommen, die wir noch nicht haben. Er [der Blinde] würde sagen, was das ist: ich denke und fühle: ich denke und höre! Hier würde in diesen drei Begriffen die ganze Metaphysik von Raum, Zeit und Kraft liegen: 
Kraft: ich denke; darum würke ich ins Universum darum bin ich Körper

Raum: ich fühle: d.i. ich denke in einer eingeschränkten Sphäre

Zeit: ich höre: d.i. ich denke Eins nach Eins!

[Here would rise a physiology of the soul and the body that we do not yet have. He [the blind man] would say what that is: I think and feel: I think and hear! Here, in these three terms, lies the whole metaphysics of space, time and force:

Force: I think; that is why I am dwelling in the universe; that is why I am body

Space: I feel: i.e. I think in a restricted sphere

Time: I hear: i.e. I think one after the other!] (Herder, Sinn 235-242).

The problem of the confluence of sensory data in perception and of specific cognitive qualities of sight and touch are also discussed in his famous essay Plastik (written between 1769 and 1770 and published in Riga in 1778). Herder identifies the specific properties of each sense and, at the same time, affirms the need to study the collaboration established by the senses in the elaboration of concepts and therefore of knowledge. Starting from the wide theoretical panorama of empirical sensualism, Herder is clearly against the assumptions formulated by Descartes, and assigns a cognitive and at the same time normative value to aisthesis, namely the sensitive world made up of human beings in flesh and blood:

Jeder Gegenstand zeigt mir gerade so viel von sich, als der Spiegel von mir selbst zeigt, das ist, Figur, Vorderseite; daß ich mehr bin, muß ich durch andre Sinne erkennen, oder aus Ideen schließen.

[Each object shows me just as much of itself as the mirror shows of myself, that is, figure, forefront; that I am more, I must recognize through other senses, or infer from ideas.] (HW IV, 249).

Therefore, concepts are an elaboration made by the body, which uses the senses starting from childhood:

Nur da wir von Kindheit auf unsre Sinne in Gemeinschaft und Verbindung brauchen: so verschlingen und gatten sich alle, insonderheit der gründlichste und der deutlichste der Sinne, Gefühl und Gesicht. Die schweren Begriffe, die wir uns langsam und mit Mühe ertappen, werden von Ideen des Gesichts begleitet: dies klärt uns auf, was wir dort nur dunkel faßten, und so wird uns endlich geläufig, das mit einem Blick weg zu haben, was wir uns Anfangs langsam ertasten mußten. Als der Körper unsrer Hand vorkam, ward zugleich das Bild desselben in unser Auge geworfen: die Seele verband beide, und die Idee des schnellen Sehens läuft nachher dem Begriff des langsamen Tastens vor.

[It is only because from childhood on we need our senses to be in communion and connection: in this way all of them intertwine and interweave, in particular the most thorough and clearest of the senses, feelings and expressions. The difficult concepts which we slowly and laboriously catch up with are accompanied by ideas of the vision: this clears up what we only grasped darkly there, and so we finally get used to having away with a glance what we had to feel slowly at first. When the body appears in our hand, the image of it is also cast into our eyes: the soul connects the two, and the idea of fast vision is later replaced by the concept of slow touch.] (HW IV, 251).

The body thus becomes a real cognitive organ and a measuring instrument of the world:

Da alle unsre Begriffe vom Menschen ausgehen oder auf inn kommen: so muß nahe diesem Mittelpunkt und der Art, wie er spinnt und würkt, die Quelle der größten Irrtümer und der sichtlichsten Wahrheit aufgespürt werden, oder sie ist nirgend.

[Since all our concepts start from human beings or come to them, the source of the greatest errors and the most visible truth must be sought out near this point and in the way he works and spins, or it will be found nowhere.] (HW IV, 253).

Also, the act of reception would follow the same process of 'simulating' the cooperation of the other senses besides sight and completing the visual data with those obtained from memory, which can be linked to the experience of form and space, perceived by the body:

Seht jenen Liebhaber, der tiefgesenkt um die Bildsäule wanket. Was tut er nicht, um sein Gesicht zum Gefühl zu machen, zu schauen als ob er im Dunkeln taste? Er gleitet umher, sucht Ruhe und findet keine, hat keinen Gesichtspunkt, wie beim Gemälde, weil tausende inm nicht gnug sind, weil, so bald es ein gewurzelter Gesichtspunkt ist, das Lebendige Tafel wird, und die schöne runde Gestalt sich in ein erbärmliches Vieleck zerstückelt. Darum gleitet er: sein Auge ward Hand, der Lichtstrahl Finger, oder vielmehr seine Seele hat einen noch viel feineren Finger als Hand und Lichtstrahl ist, das Bild aus des Urhebers Arm und Seele in sich zu fassen.

[Look at that lover, who swings deeply around the statue. What does he not to turn his vision into a feeling, to look as if he is tasting in the dark? He glides around, seeks rest and finds none, has no point of view, as in the painting, because thousands are not enough for him, because, as soon as he gets a rooted point of view, the Image of the Living appears, and the beautiful round figure fragments into a pitiful polygon. Therefore, he glides: his eye became a hand, the ray of light a finger, or rather his soul has a much finer finger than hand and ray of light do have, in order to contain within itself the image of the author's arm and soul.] (HW IV, 255).

The body intended as a unitary sensory organ 'reflects within itself', embodying what is perceived outside, and storing such data in a memorial fluxus, functional to every new cognitive process:

Jede Empfindung in der Jugendseele ist nicht bloß was sie ist, Materie, sondern auch aufs ganze Leben Materie: sie wird nachher immer verarbeitet, und also gute Organisation, viele, starke, lebhafte, getreue, eigne Sensationen, auf die dem Menschen eigenste Art sind die 
Basis zu einer Reihe von vielen starken, lebhaften, getreuen, eignen Gedanken, und das ist das Original Genie [...]

[Every sensation in the young soul is not only what it is, matter, but also a lifelong matter: it is processed again and again and therefore all good organisations, many strong, lively, faithful, own sensations, in the most own way, are the basis for a series of many strong, lively, faithful, own thoughts, and that is the original genius [...]] (HW IX/2, 121).

Conceptualization is therefore considered as the result of the elaboration of sensorial perception which, through the action of memory and its subsequent elaborations, becomes language, personal and cultural heritage which in turn gives rise to the perceived and transmitted reality:

Durch Repräsentation der Sachen fürs Gesicht, noch mehr aber Gefühl: durch Körperliche Übungen und Erfahrungen allerlei Art, durch Bedürfnisse und Ersättigungen, wie sie nur sein können. Alles versteht sich pro positu, in welcher Art von Welt man lebt, und sehen kann.

[By representing things for the vision, but even more for touch: through physical exercises and experiences of all kind, through any needs and satisfactions, everything is understood pro positu, in whatever kind of world one lives and can see.] (HW IX/2, 122).

Thought finds thus its articulation in narration, which connects or contrasts data, emotions and memories in a sequence that fills the human mind like a continuous flow:

Der gewöhnliche Lauf unsrer Gedanken geht so schnell; die Wellen unsrer Empfindungen rauschen so dunkel in einander: es ist auf einmal so viel in unsrer Seele, daß wir in Absicht der meisten Ideen wie im Schlummer an einer Wasserquelle sind, wo wir freilich noch das Rauschen jeder Welle hören, aber so dunkel, daß uns endlich der Schlaf alles merkbare Gefühl nimmt. Wäre es möglich, daß wir die Kette unsrer Gedanken anhalten, und an jedem Gliede seine Verbindung suchen könnten - welche Sonderbarkeiten! welche fremden Analogien der verschiedensten Sinne, nach denen doch die Seele geläufig handelt!

[The ordinary course of our thoughts goes so fast; the waves of our sensations rush so darkly into each other: there is so much in our souls all at once as if we were asleep at a water spring, where we can still hear the sound of each wave, but the sleep finally takes away all noticeable feelings. Would it be possible that we could stop the chain of our thoughts and seek its connection at every part of the body - what peculiarity! what strange analogies of the most diverse senses, according to which the soul usually acts] (HW I, 745).

\section{b) Analogon, unity of the existing (Embedded Mind)}

At the basis of Herder's embodied theorization is the principle of the Analogon (see Irmscher, Verra, Löchte and Simon for detailed studies), a complex concept which links the embodied theory of cognition with that of aesthetic reception, which is as well rooted in sensory perception, as highlighted by Hans Adler in the essay Was ist vergleichen bei Herder, to be found in Allert's book (Allert 22-37). Analogon, which appears at the beginning of the treatise Vom Erkennen und Empfinden der menschlichen Seele, in the Erster Versuch entitled Vom Erkennen und Empfinden in ihrem Ursprunge und den Gesetzen ihrer Würkung. Bemerkungen und Träume, is defined as follows: "[...] Analogie, das Gefühl von dem Einen, der in aller Mannigfaltigkeit herrschet [...]" [the feeling of the one who prevails in all diversity]"; "[...] der empfindende Mensch fühlt sich in Alles, fühlt Alles aus sich heraus, und druckt darauf sein Bild, sein Gepräge" [the sentient person feels in everything, feels everything out of himself, and prints his image, his impression on it)" (HW IV, 331). More specifically, the principle of Analogon appears as a mental image, or rather, in cognitive terms, an image schema, from which one may proceed in the elaboration of perceptions in narrative sequences:

Der Mensch ist ein Inbegrif der ganzen Welt, der sichtbaren u. unsichtbaren, selbst Gottes. Er könnte von keiner Eigenschaft Geistes u. Körpers im Universum einen Begrif, noch weniger ein Gefühl haben, wenn er nicht ein Analogon davon in sich besäße.

[Man stands for the whole world, the visible and invisible, even for God. He would have no idea, much less a feeling of any quality of spirit or body in the universe, without bearing an Analogon within himself.] (Herder, Brief 1034).

Herder's concept of Analogon has a physical nature, since it originates from the Reiz [stimulus], which moves from a "schlagendes Herz" [beating heart] and crosses a "feines Faserngewebe" [fine fibre fabric] that pervades the body, reaching the nervous system. Herder draws these principles from Bonnet's Essai de psychologie and Robert Boyle's Korpuskularlehre (Häfner 398). He further adopts these concepts to theorize the existence of man as "whole man", or as sensorium of the whole universe, moving the focus from the dimension of the human being as "sensorium numinis" to the purely anthropological dimension of corporeity understood as the origin of all phenomena. As we read in the Paralipomena to the essay Plastik: "Unser Körper ist nur ein Bild unsrer Seele $(\alpha v \theta \rho\langle\omega \pi$ < $\Psi v \chi\langle ı \kappa \varsigma\rangle)$ u. diese nur der Keim zum Geist $(\pi v\langle\varepsilon v \mu \alpha\rangle)$ der aus inm erwachsen $u$. sein Wesentlichstes überkleiden soll" (Our body is only an image of our soul ( $\alpha v \theta \rho\left\langle\omega \pi \sigma \varsigma \Psi v \chi\left\langle{ }_{1 \kappa o s}\right\rangle\right)$ and this is only the germ of the spirit $(v\langle\varepsilon v \mu \alpha\rangle)$ which should grow out of it and cover its most essential parts] (Häfner 398).

On the one hand, the concept of the body intended as sensorium of the world and image of the world's soul postulates the principle of identification of the microcosm with the macrocosm; on the other hand, it attests the premises for a mirroring effect, which is not merely metaphorical, but mainly physical: "Wie unsere 
ganze Psychologie aus Bildwörtern besteht, so war es meistens ein neues Bild, eine Analogie, ein auffallendes Gleichnis, das die größten und kühnsten Theorien geboren hat. [...] Was wir wissen, wissen wir nur aus Analogie, von der Kreatur zu uns und von uns zum Schöpfer." [As all our psychology is made up by pictorial words, it was usually a new image, an analogy, a striking simile that gave birth to the greatest and most daring theories. [...] What we know, we know only by analogy, from the creature to us and from us to the Creator.] (HW IV, 331).

What defines Analogon is the sharing of the common laws of nature through corporeity, an assumption that allows Herder to create an 'ecological' vision of life, in which the same vital laws of other forms of life in nature are at work in the human being, as it is extensively expounded in Ideen zur Philosophie der Geschichte der Menschheit (1784-1791):

Unter der Erde fängt diese Vielartigkeit an und sie wächst hinauf durch Pflanzen, Tiere, bis zum vielartigsten Geschöpf, dem Menschen. Sein Blut und seine vielnamigen Bestandteile sind ein Kompendium der Welt: Kalk und Erde, Salze und Säuren, Öl und Wasser, Kräfte der Vegetation, der Reize, der Empfindungen sind in inm organisch vereint und in einander verwebet.

[This diversity begins under the earth, and it continues to grow through plants, animals and even the most diverse creature, the human being. His blood and his many named components are a compendium of the world: lime and earth, salts and acids, oil and water, the forces of vegetation, stimuli and sensations are organically united and interwoven in him.] (HW IV, 168).

According to Herder, the active principle of perception is identified in the "Reiz" [stimulus], defined as "die Triebfeder unsres Daseins" [the driving force of our existence], corresponding in nature to the laws of excitation, expansion and contraction, from which derives the contrast between hot and cold:

Was in der toten Natur Ausbreitung und Zurückziehung, Wärme und Kälte ist: das scheinen hier diese dunklen Stamina des Reizes zur Empfindung: eine Ebbe und Flut, in der sich, wie das Weltall, so die ganze empfindende Natur der Menschen, Tiere, und wo sie sich weiter hinab erstrecke, bewegt und reget.

[Similar to what in inert nature are expansion and retreat, warmth and cold, is the dark stamina of attraction for our senses: an ebb and flow, in which, like the universe, the whole sentient nature of people, animals, and where it extends further down, moves and stirs.] (HW IV, 334).

Herder identifies the vital organic principle of the existing (the spirit) in the process of breathing, which along several stages of complexity leads to an exchange between the body and the environment. This happens in progressive levels of complexity in plants as well as in animals and in human beings. This issue is not to be understood in a theological way, but as the 'selbst innigste, würkendste Kraft [der Natur]' [the most intimate, active power [of nature]] (HW IV, 339). As a result, Herder postulates the unity of body, mind and spirit, as rooted in the organicity of all the existing beings, and reflected at best in the human being:

Der innere Mensch mit all seinen dunklen Kräften, Reizen und Trieben ist nur Einer. Alle Leidenschaften, ums Herz gelagert, und mancherlei Werkzeuge regend, hängen durch unsichtbare Bände zusammen und schlagen Wurzel im feinsten Bau unsrer beseelten Fibern. Jedes Fäserchen, wenn wirs einsehen könnten, gehört ohne Zweifel mit dazu, jedes engere und weitere Gefäß, jede stärker und schwächer wallende Blutkugel.

[The inner nature of the human being with all his dark powers, stimuli and drives is only one. All passions stored around the heart, and some stirring tools are tied together by invisible bonds and take root in the finest structure of our soulful fibres. Every little fibre, if we could see it, is without doubt part of it, every narrow and wider vessel, every ball of blood flowing stronger and weaker.] (HW IV, 339)

Central categories around which the unity of existence is hinged are "Elastizität" [elasticity], "Reizbarkeit" [irritability] and "Sinnlichkeit" [sensuality], which Herder probably borrowed from Haller (Barr Nisbet 256). The principle of Elastizität appears in the first lines of Vom Erkennen und Empfinden der menschlichen Seele and is explained in terms of a force that gives movement and action to the whole - "der erste scheinbare Funke zur Tätigkeit in edlen Naturen" [the first apparent spark of activity in noble natures] giving impulse to the manifestation of the "Seele der Welt" [soul of the world], the "allgegenwertiger Lebensgeist" [omnipresent spirit of life], the two main opposing forces of attraction and repulsion, present in the "elektrischer Strom" [electrical storm] (HW IV, 330): "Überhaupt ist in der Natur nichts geschieden, alles fließt durch unmerkliche Übergänge auf- und ineinander; und gewiß, was Leben in der Schöpfung ist, ist in allen Gestalten, Formen und Kanälen nur Ein Geist, Eine Flamme. [In nature, nothing is separate, everything flows through imperceptible transitions to and into each other; and certainly, what is life in creation exists in all forms, shapes and channels only as one spirit and one flame.] (HW IV, 335).

\section{c) Erkennen und Empfinden (Enacted Mind - Cognition) \\ "Erkenntnis und Empfindung leben nur in Tat} (Knowledge and sensation live only in action)" (HW IV, 376). This strong and unequivocal assumption postulates not only the co-participation of the emotional dimension in the cognitive act, but also the centrality of action in the gnoseological process, as already proposed by Bonnet in the triad "Empfinden - Denken Handeln" [Feel - Think - Act] (Häfner 406). The core of this revolutionary concept of cognition is the codetermination between cognitive and emotional processes, according to which "unsre Empfindungen, 
Glieder und Triebe [...] einander binden, anregen und stärken [our sensations, limbs and drives [...] are bound, stimulate and strengthen each other)" (HW IV, 352). It is therefore not surprising that the first paragraph of the second part of Vom Erkennen und Empfinden der menschlichen Seele is apodictically entitled as follows: "Unser Denken hängt ab vom Empfinden" [Our thinking depends on feeling] (HW IV, 366). The codetermination of thought and emotion, not univocally placed in the philosophical thought of his time (see Sauder and Vila for a detailed study), emerges in Herder with strength, both at the level of the human action and at that of the determinations of entire nations: "Wie einzelne Menschen, so sind noch mehr Familien und Völker von einander verschieden: nach dem Kreise ihrer Empfindungs- richtet sich auch ihre Denkart" [Like single individuals, even families and peoples are different from each other: their way of thinking depends on the circle of their way of feeling and thinking)". (HW IV, 369).

Emotion, on an individual level, is described by Herder as one of the main interacting sources in the process of perception and knowledge of the world:

Oft liegen unter dem Zwergfell Ursachen, die wir sehr unrichtig und mühsam im Kopf suchen; der Gedanke kann dahin nicht kommen, wenn nicht die Empfindung vorher an inrem Ort war. Wie fern wir an dem, was uns umgibt, Teil nehmen, wie tief Liebe und $\mathrm{HaB}$, Ekel und Abscheu, Verdruß und Wollust ihre Wurzeln in uns schlagen; das stimmt das Saitenspiel unsrer Gedanken, das macht uns zu denen Menschen, die wir sind.

[Often there are causes under the diaphragm which we search for very incorrectly and laboriously in our head; the thought cannot come to that place if the sensation has not been there before. How far we take part to what surrounds us, how deeply love and hate, disgust and loathing, annoyance and lust take their roots in us; this is what makes us the people we are.] (HW IV, 340-341).

The nature of human emotions is not distinct from the physical nature of bodies, although it manifests itself through different forces, namely those of electrical irritability, capable of animating matter, as Herder himself states, a principle derived from Haller's theory. In the same way that Haller had identified in the "Reiz" [stimulus] both external stimuli and internal stimuli, Herder sees in the stimulus the strenght that pervades the organic nature:

Hat man je etwas Wunderbarers gesehen als ein schlagendes Herz mit seinen unerschöpflichen Reizen? Ein Abgrund innerer dunkeln Kräfte, das wahre Bild der organischen Allmacht, die vielleicht inniger ist, als der Schwung der Sonnen und Erden. Und nun breitet sich aus diesem unerschöpflichen Brunnen und Abgrunde der Reiz durch unser ganzes Ich aus, belebt jede kleine spielende Fiber - alles nach Einartigen einfachen Gesetzen.

[Have you ever seen anything more wonderful than a beating heart with its inexhaustible stimuli? An abyss of inner dark forces, the true image of organic omnipotence, which is perhaps more intimate than the swing of the sun and earth. And now, from this inexhaustible well and abyss, the stimulus spreads through our whole self, enlivens every little playing fibre - all according to such simple laws.] (HW IV, 333).

Compared to the theory of affections of his epoch, Herder had a brilliant intuition on the relationship between body and emotions, only recently acquired by science (see Caruana and Viola for further discussion), specifically from the studies of the neuroscientist Damasio: in this new perspective, diverging from other orientations in affective science and in the philosophy of emotions, emotion is not considered as an immaterial feeling, but as a consequence of a reaction of the body, of chemical and neural nature, i.e. a somatic alteration determined by a specific situation perceived by the limbic brain and transmitted to the somato-sensory cortex, which in turn forms a representation of the modification of bodily schemes. For example, when facing an event perceived by the limbic brain as a danger, heartbeat and sweating increase: these are somatic phenomena which have a motivational effectiveness (fleeing from possible danger) and which we perceive as fear on the level of the phenomenological experience. Herder describes this process as follows:

Wenn wir uns wohl befinden, ist unsre Brust weit, das Herz schlägt gesund, jede Fiber verrichtet ihr Amt im Spiele. Da fährt Schrecken auf uns zu; und siehe als erste Bewegung, noch ohne Gedanken von Furcht und Widerstande, tritt unser reizbares ich auf seinen Mittelpunkt zurück, das Blut zum Herzen, die Fiber, selbst das Haar, starrt empor; gleichsam ein organischer Bote zur Gegenwehr, die Wache steht fertig.

[When we are well, our chest is wide, the heart beats healthy, every fibre does its job. Then horror comes upon us; and behold, as the first movement, still without thoughts of fear and resistance, our irritable self steps back to its centre, the blood to the heart, the fibre, even the hair, stares up; as it were an organic messenger to fight back, the guard stands ready.] (HW IV, 333).

The inner dimension of the human being is inseparable from the corporeal one:

Meines geringen Erachtens ist keine Psychologie, die nicht in jedem Schritte bestimmte Physiologie sei, möglich. Hallers physiologisches Werk zur Psychologie erhoben und wie Pygmalions Statue mit Geist belebet als denn können wir etwas übers Denken und Empfinden sagen.

In my opinion, no psychology that is not specific physiology is possible. Haller's physiological work elevated to psychology and, like Pygmalion's statue, enlivened with spirit - as if we could say something about thinking and feeling. (HW IV, 341).

In the soul, thought and emotion coincide, drawing strength from the body and from the vital nutrients processed from food. In opposition to Leibniz' vision put out in the Monadologie, Herder's idea is that 
the soul does not produce content from the inside, but from the body and the environment, with which it is related through an analogical relationship:

[...] menschliche Seele [...]. Ihr Denken wird nur aus Empfindung: ihre Diener und Engel, Luft- und Flammenboten strömen ihr ihre Speise zu, so wie diese nur in ihrem Willen leben. [...] Ich kann mir überhaupt nicht denken, wie meine Seele etwas aus sich spinne und aus sich eine Welt träume? ja nicht einmal denken, wie sie etwas außer sich empfinde, wovon kein Analogon in ihr und ihrem Körper sei. Wäre in diesem Körper kein Licht, kein Schall: so hätten wir auf aller weiten Welt von nichts, was Schall und Licht ist, Empfindung: und wäre in ihr selbst, oder um sie, nichts dem Schall, dem Licht Analoges, noch wäre kein Begriff dessen möglich.

[[...] human soul [...]. Its thinking comes only from sensation: its servants and angels, messengers of air and flames stream their food to it, just as these only live in its will. [...] I cannot imagine, how my soul could spin something out of itself and dream a world out of itself. I cannot even imagine, how it feels something out of itself, of which there is no analogue in it and in the body. If there were no light, no sound in this body, we would have no sensation in the whole wide world of what is sound and light: and if there were nothing analogous to sound or light in her, or around her, no concept of it would be possible.] (HW IV, 354).

The concept of soul loses all its immateriality, since it emerges from nature, i.e. from the univocal substance of the whole living:

Aber so wäre ja die Seele materiell? oder wir hätten gar viele immaterielle Seelen? So weit sind wir noch nicht, mein Leser; ich weiß noch nicht, was Material oder Immaterial sei? glaube aber nicht, daß die Natur zwischen beiden eiserne Bretter befestigt habe, weil ich die eisernen Bretter in der Natur nirgend sehe und gewiß da am wenigsten vermuten kann, wo die Natur so innig vereinte.

[So, the soul would be material? Or would we even have many immaterial souls? We have not yet reached that point, my reader; Do I know yet what material or immaterial is? I don't think that nature has fixed iron planks between the two, because I see the no iron planks in nature, and I can certainly least suspect their presence where nature has been so intimately united.] (HW IV, 355).

The concept of soul does not imply a salvific metaphysics in religious terms, but remains strongly anchored within the natural dimension of vital forces resulting from the interaction of energy, thought and emotion:

Ist Seele das, was wir fühlen, wovon alle Völker und Menschen wissen, was auch der Name sagt, das nämlich, was uns beseelt, Urgrund und Summe unsrer Gedanken, Empfindungen und Kräfte: so ist von ihrer Unsterblichkeit aus ihr selbst keine Demonstration möglich.

[If the soul is what we feel, what all peoples know, what its name says, that is, what animates us, the source and sum of our thoughts, feelings and powers, then no demonstration of its immortality is possible.] (HW IV, 394).

Herder's perspective links the evolution of the individual soul to that of the social body, which, like the former, can develop in a process of growth and improvement, according to a project that leads from the individual Bildung [education] to that of mankind, and finally to the realization of the highest potential of humanity, as masterfully summarized by SchmidtBiggemann:

[...] die Seele sieht sich und wird gesehen im Prozeß der Selbstveränderung und Verbesserung zur Empfindungseinheit, einem Prozeß, der für den einzelnen Menschen emphatisch Bildung, für seine Gattung Erziehung zur Humanität heißt.

Erziehungsziel für den Einzelnen und fürs Menschengeschlecht ist Humanität, der Status des verwirklichten ganzen Menschen. [...] Der Gedanke bürgerlicher Erziehung wird [...] theologischphilosophisch als Erziehung des Menschengeschlechts zur Autonomie überhaupt, die die Natur des Menschen am Menschen vollzog.

$[[\ldots]$ the soul sees itself and is seen in the process of selftransformation and improvement to a unity of feeling, a process which for the individual person is emphatically called education, for his species education to humanity.

The educational goal for the individual and for the human race is humanity, the status of the realised whole human being. [...] The idea of civic education evolves [...] theologically and philosophically as the education of the human race to autonomy, which the nature of the human being carried out on the human being.] (SchmidtBiggemann, Einführung, in Schings 12).

Divine and human are combined by projecting the individual soul and the whole community into a unitary scheme, which overcomes the limit and opacity of matter, enhancing cognitive faculties through individual and collective Bildung [education], and reaching a higher and more evoluted level of humanity. This idea brings together the physiological, ethical and political discourse in one cognitive project that joins the individual and the collective evolution. The medium for that is the new concept of aesthetics, understood as a process that leads from the senses to a continuous act of construction of meaning and of Bildung, intended as the true modus operandi of human kind at the level of culture. Herder contrasts an abstract concept of aesthetics with one that is extremely related to the sensory perception in Über Bild, Dichtung und Sprache: here he defines aesthetics as the "Philosophie der sinnlichen Empfindungen" [philosophy of sensual feelings], which summarises "[...] sowohl den Umfang seiner Gegenstände, als das Subjekt ihrer Wirkung [...]. Eine Philosophie des Geschmacks, des Schönen u.f., die nur von Einem Sinne ausginge, müßte zur Philosophie der gesamten Empfindungen notwendig nur unvollkommene Bruchstücke liefern." [[...] both the 
scope of its objects and the subject of its effects [...]. A philosophy of taste, beauty, etc., which would emanate from only one sense, would have to provide only imperfect fragments for the philosophy of all sensations.] (HW IV, 635).

d) Theory on the origin of language, "Würkungskreis /circle of activity (Extended Mind)

Nur die Sprache hat den Menschen menschlich gemacht, indem sie die ungeheure Flut seiner Affekten in Dämme einschloß und ihr durch Worte vernünftige Denkmäler setzte.

[Only language made man human, by damming up the immense flood of his affects, and by giving him reasonable monuments through words.] (HW VI, 347).

This Herder's idea in Ideen zur Philosophie der Geschichte der Menschheit of 1791, further developing the reflections of his theory of language formulated in the famous Abhandlung über den Ursprung der Sprache (1772), a work for which he received the prize from the Akademie der Wissenschaften in Berlin (see Aarsleff and Derrida regarding the debate on language).

A premise adopted by Herder regarding the origin of language is the concept of 'necessity', of 'unmittelbares Naturgesetz' [immediate natural law] (HW I, 747), which dominates every living being endowed with senses and acting as an 'empfindende Maschine' [sentient machine)] (HW I, 747):

Hier ist ein empfindsames Wesen, das keine seiner lebhaften Empfindungen in sich einschließen kann; das im ersten überraschenden Augenblick, selbst ohne Willkür und Absicht, jede in Laut äußern muß. Das war gleichsam der letzte, mütterliche Druck der bildenden Hand der Natur, daß sie allen das Gesetz auf die Welt mitgab: 'Empfinde nicht für dich allein: sondern dein Gefühl töne!'

A sentient being cannot contain any of his lively sensations; in the first surprising moment, even without arbitrariness or intention, he must express each one in sound. To give everyone the law of the world was the last maternal gift of nature's creative hand: 'Do not feel for yourself alone but let your feeling sound!'. (HW I, 699).

Unlike Rousseau's and Condillac's theories, Herder's concept of sensitivity implyes expression (enaction). Language is not understood as a world of signs, but as the expression of sensations and emotions; therefore, it is indicated as "Tiersprache" [animal language], a substratum common to all sensitive beings. However, if its origin is to be found in the sensitive nature of the body, its raison d'être is the awareness of belonging to a biosphere in which we are not "abgesonderte Steinfelsen" [separate stone cliffs] or "egoistische Monaden" [selfish monads], but individuals belonging to the same sensitive existence: "Deine Empfindung töne deinem Geschlecht einartig und werde also von allen wie von einem mitfühlend vernommen!" [Your sensation is unique to your sex and is heard by all as if by one!] (HW I, 699).
In Herder's opinion, the ability to transmit sensations and emotions is not due to a divine gift, but to the common biological substance of all sensitive bodies (extended mind):

Zartbesaitet, aber die Natur hat in diese Saiten Töne verborgen, die, gereitzt und ermuntert, wieder andre gleichzart gebaute Geschöpfe wecken, und wie durch eine unsichtbare Kette, einem entfernten Herzen Funken mitteilen können, für dies ungesehene Geschöpf zu fühlen - Diese Seufzer, diese Töne sind Sprache. Es gibt also eine Sprache der Empfindung, die unmittelbares Naturgesetz ist.

[Softly stringed, nature has hidden in these strings sounds which, when solicited and encouraged, can awaken other equally softly built creatures, and as if, through an invisible chain, can send sparks to a distant heart to feel for this unseen creature:: These sighs, these sounds are language. So, there is a language of feelings which is an immediate natural law.] (HW I, 699).

According to Herder, the need to express with sounds or gestures one's own emotional state derived from the senses is not a human peculiarity, but a "mirror" property of the bodies that humans share with all sensitive being:

Je harmonischer das empfindsame Saitenspiel selbst bei Tieren mit andern Tieren gewebt ist: desto mehr fühlen selbst diese miteinander; ihre Nerven kommen in eine gleichmäßige Spannung, ihre Seele in einen gleichmäßigen Ton, sie leiden würklich mechanisch mit.

[The more harmoniously the sensitive play of the strings is woven with other animals, the more even these animals feel with each other; their nerves come into an equal tension, their soul into an equal tone, they suffer mechanically.] (HW I, 705-6).

Starting from the common sensitive substratum, Herder proceeds in identifying the peculiarities of human language, according to the principle of differentiation of what he calls "Würkungskreis", i.e. the context within which the organism acts and interacts:

Jedes Tier hat seinen Kreis, in den es von der Geburt an gehört, [...] je schärfer die Sinne der Tiere, je wunderbarer ihre Kunstwerke sind, desto kleiner ist ihr Kreis: desto einartiger ist ihr Kunstwerk. [...] ich finde überall eine wunderbare beobachtete umgekehrte Proportion zwischen der mindern Extension ihrer Bewegungen, Elemente, Nahrung, Erhaltung, Paarung, Erziehung, Gesellschaft und ihren Trieben und Künsten.

[Every animal has its circle, into which it belongs from birth, [...] the sharper the senses of the animals, the more wonderful their works of art are, the smaller their circle is and the more unique their work of art is. [...] I find everywhere a wonderful observed inverse proportion between the reduced extension of their movements, elements, food, preservation, mating, education, society and their drives and art products.] (HW I, 713).

A deep linkage connects the amazing creation of human language, words, concepts and judgements 
allowing not only the communication of individual messages, but of entire fictional worlds, to action:

'Die Empfindsamkeit, Fähigkeiten und Kunsttriebe der Tiere nehmen an Stärke und Intensität zu, im umgekehrten Verhältnisse der Größe und Mannigfaltigkeit ihres Würkungskreises'. Nun aber -

Der Mensch hat keine so einförmige und enge Sphäre, wo nur Eine Arbeit auf inn warte: mithin kein Kunsttrieb, keine Kunstfertigkeit - und, das eine gehört hier näher her, keine Tiersprache. (HW I, 714).

Seine Sinne und Organisation sind nicht auf eins geschärft: er hat Sinne für alles und natürlich also für jedes einzelne schwächere und stumpfere Sinne.

['The sensitivity, abilities and artistic drives of animals increase in strength and intensity, in inverse proportion to the size and diversity of their circle of action'.

But now -

The human being does not have such a uniform and narrow sphere, where only one work awaits him: thus no artistic instinct, no artistry - and, one thing belongs here closer, no animal language.

His senses and organisation are not focused on one thing: he has senses for everything and of course for every single weaker and duller sense. (HW I, 714).

Human language is, according to Herder, the result of the expansion of the human 'sphere of action', of the consequent insufficient specificity of individual sensory faculties, compensated by the expansion of the imaginative capacity beyond the limit of physiological needs. This extension of the horizon endowes the human being not only with the freedom to perceive himself as an individual within an environment, but also to meditate on himself and his actions in the world:

[...] so wird er [der Mensch] freistehend, kann sich eine Sphäre der Bespiegelung suchen, kann sich in sich bespiegeln. Nicht mehr eine unfehlbare Maschine in den Händen der Natur, wird er sich selbst Zweck und Ziel der Bearbeitung.

$[[\ldots]$ then he [the human being] becomes free, can look for a mirroring sphere, can mirror himself. No longer an infallible machine in the hands of nature, he becomes himself the purpose and aim of the work.] (HW I, 718).

It is therefore not a higher level of communication with others that determines the uniqueness of human language, but its being the product of what we would define as extended mind, deriving from the interaction with others and with the environment. Context codetermins human consciousness, identity, judgement, and the peculiarities of language:

Es ist die 'ganze Einrichtung aller menschlichen Kräfte; die ganze Haushaltung seiner sinnlichen und erkennenden, seiner erkennenden und vollendeten Natur,' oder vielmehr - es ist 'die Einzige positive Kraft des Denkens, die mit einer gewissen Organisation des Körpers verbunden bei den Menschen so Vernunft heißt, wie sie bei den Tieren Kunstfähigkeit wird: die bei ihm
Freiheit heißt, und bei den Tieren Instinkt wird'. Der Unterschied ist nicht in Stufen oder Zugabe von Kräften, sondern in einer ganz verschiedenartigen Richtung und Auswickelung aller Kräfte.

[It is 'the whole institution of all human powers; the whole household of his sensual and cognitive, his cognitive and perfect nature,' or rather - it is 'the only positive power of thought which, connected with a certain organisation of the body, is called reason in humans as it becomes art in animals: which in him is called freedom, and in animals becomes instinct'. The difference is not in steps or addition of forces, but in a quite different direction and unfolding of all forces.] (HW I, 718).

The element which expresses the profound difference between humans and animals is the quality of thought and reflection, which creates in the human being the deep need to give shape to his/her inner world as well as to the world around him, activating the production of a tool to shape mental images derived from sensory and emotional experiences. Human language exists by virtue of man's ability to look at himself and the world, transferring out of himself his own experience through the word in first person and through narration in third person.

Der Mensch in den Zustand von Besonnenheit gesetzt, der ihm eigen ist, und diese Besonnenheit (Reflexion) zum erstenmal frei würkend, hat Sprache erfunden. Denn was ist Reflexion? Was ist Sprache? [...] Der Mensch beweiset Reflexion, wenn die Kraft seiner Seele so frei würket, daß sie in dem ganzen Ozean von Empfindungen, der sie durch alle Sinnen durchrauschet, Eine Welle, wenn ich so sagen darf, absondern, sie anhalten, die Aufmerksamkeit auf sie richten, und sich bewußt sein kann, daß sie aufmerke. [...] Er beweiset also Reflexion, wenn er nicht bloß alle Eigenschaften, lebhaft oder klar erkennen; sondern eine oder mehrere als unterscheidende Eigenschaften bei sich anerkennen kann: der erste Aktus dieser Anerkenntnis giebt deutlichen Begriff; es ist das Erste Urteil der Seele - und - wodurch geschahe die Anerkennung? Durch ein Merkmal, was sehr absondern mußte, und was, als Merkmal der Besinnung, deutlich in inn fiel. [...] Dies Erste Merkmal der Besinnung war Wort der Seele! Mit inm ist die menschliche Sprache erfunden.

[The human being, placed in the state of self-reflecting, and freely expressing these thoughts for the first time, has invented language. For what is thought? What is language? Man demonstrates self-reflection when the power of his soul becomes so free that despite the whole ocean of sensations that rushes through all the senses, he is able to separate a wave, if I may say so, stop it, direct attention to it, and be aware that he is attentive. [...] He proves to be reflecting when he is able not only to recognize all the qualities, vivid or clear, but also to recognize one or more of them as distinguishing qualities in himself: the first act of this recognition gives birth to a clear concept; it is the soul's first judgement - and - what is the reason for this recognition? By a characteristic which had to be very distinct, and which, as a characteristic of reflection, fell clearly within it. [...] This 
first characteristic of reflection was the word of the soul! Human language was invented with it.] (HW I, 723-4).

As can be deduced from this important excerpt, the first word originates from the action of a vital energy, indicated here by Herder as Seele [soul], in order to express the embodied cognitive act of Vernunft [reason] through self-reflection, as well as the narrativization of his experience through words: "[...] alle Zustände der Besonnenheit in inm [werden] sprachmässig: seine Kette von Gedanken wird eine Kette von Wortern." [[...] all states of self-reflection [become] in him linguistic: his chain of thoughts becomes a chain of words." (HW I, 775).

Language is not only an expression of Empfindungen (feelings), or of other human faculties such as Vernunft and Besonnenheit, but also an instrument capable of shaping the world, connecting natural history to the education of individuals and societies, and evolving, according to the laws of transformation that Herder traces out as valid for the cultural history of humanity. The different evolutionary levels of language are expressed in style, which means that the language of poetry corresponds to an era of primordial harmony, while prose corresponds to modernity, which can and must further expand its strength, in an inversion of its still unexpressed qualities. Language is, in fact, where human experience, natural and cultural, history and tradition interact, express and show themselves to the external world.

The relevance attributed to the corporeal dimension has allowed Herder to explore the most mysterious aspects of life, of the human mind and soul, as well as of history, philosophy and in the development of civilizations. The reinterpretation of his works in a cognitivist key allows us to appreciate Herder's work in the perspective of a global theory about the human being, able to overcome the gap between nature and culture. At the same time, Herder's cognitive issues allow us to rediscover the philosophical substratum of current scientific theories, whose premises draw back to the philosophical debate of the eighteenght Century. Thus, in a transdisciplinary perspective, we can resume the reflection on some still unsolved mysteries, which the human being has been facing since the beginning of time: mind, consciousness, imagination, memory, and most of all his/her being both a destroying demon and a creature capable of the highest works of genius. (RG)

\section{APPENDIX}

This study, part of a wider ongoing work on Johann Gottfried Herder, is the result of a collaborative research carried out by the two co-authors, whose names are indicated by initials in parentheses in the text.

\section{AKNOWLeDgment}

The authors would like to thank Vittorio Gallese, discoverer of the Mirror Neurons, (together with Giacomo Rizzolatti and the team from Parma), and expert of embodiment, for the stimulating discussions during the last few years, both in relation to his laboratory research and to issues of aesthetics that few people like him are familiar with. A further thanks, always, to Semir Zeki, who taught us to investigate literary and philosophical texts in relation to the human mind.

\section{References Références Referencias}

1. Aarsleff, Hans. Da Locke a Saussure. Saggi sullo studio del linguaggio e la storia delle idee. Mulino, 1984.

2. Allert, Beate, editor. Herder: From Cognition to Cultural Science. Synchron, 2016.

3. Barr Nisbet, Hugh. Herder and the Philosophy of Science. The Modern Humanities Research Association, 1970.

4. Baumgarten, Alexander Gottlieb. Aesthetika. Kleyb, 1750-58.

5. Baumgarten, Alexander Gottlieb. Metaphysica. Hildesheim, 1982, p. 176.

6. Beetz, Manfred, Garber, Jörn and Thoma, Heinz, editors. Physis und Norm. Neue Perspektiven der Anthropologie im 18. Jahrhundert. Wallstein, 2007.

7. Borchers, Stefan. Die Erzeugung des »ganzen Menschen«. Zur Entstehung von Anthropologie und Ästhetik an der Universität Halle im 18. Jahrhundert. De Gruyter, 2011.

8. Borchers, Stefan. "Totus homo oder ganzer Mensch? Zum Auftakt der Anthropologie an der Universität Halle." Die Sachen der Aufklärung. Beiträge zur DGEJ-Jahrestagung 2010 in Halle a.d. Saale, AA. WV., Meiner Verlag, 2012, pp. 552-59.

9. Brown, John. Elements of Medicine. Webster, 1780.

10. Caruana, Fausto and Viola, Marco. Come funzionano le emozioni, II Mulino, 2018.

11. Cassmann, Otto. Psychologia anthropologica: sive animae humanae doctrina methodice informata capitibus dissecta singolorumque capitum disquisitionibus ac controversarum questionem ventilationibus illustrata. Fischerus, 1594.

12. Clark, Andy and Chalmers, David. "The Extended Mind." Analysis, 1998, vol. 58, no. 1, pp. 7-19.

13. Colombetti, Giovanna and Thompson, Evan. "II corpo e il vissuto affettivo: verso un approccio «enattivo» allo studio delle emozioni." Rivista di estetica, 2008, vol. 37, pp. 77-96.

14. Cuccio, Valentina, Carapezza, Marco and Gallese, Vittorio. "Metafore che risuonano. Linguaggio e corpo tra filosofia e neuroscienze." EC. Rivista dell'Associazione Italiana Studi Semiotici, vol. 7, no. 17, 2013, pp. 69-74. 
15. Damasio, Antonio. L'errore di Cartesio. Emozione, ragione e cervello umano, Adelphi, 1995.

16. Damasio, Antonio. Self Comes to Mind: Constructing the Conscious Brain. Pantheon Books, 2010.

17. Damasio, Antonio et al. "Subcortical and cortical brain activity during the feeling of self-generated emotions." Nature Neuroscience, 2000, vol. 3, pp.1049-56.

18. Deacon, Terrence. "The Aesthetic Faculty". The Artful Mind, edited by M. Turner, Oxford UP, 2006.

19. Derrida, Jacques. L'archeologia del frivolo. Saggio su Condillac. Dedalo, 1992.

20. De Angelis, Simone. Anthropologien. Genese und Konfiguration einer «Wissenschaft vom Menschen» in der Fruihen Neuzeit. De Gruyter, 2010.

21. Faschilli, Claudio. "La negazione e le teorie simulative della comprensione linguistica." Rivista Italiana di Filosofia del Linguaggio. Azione, percezione e linguaggio, 2012, vol. 5.

22. Freedberg, David and Gallese, Vittorio. "Motion, Emotion and Empathy in Aesthetic Experience." Trends in Cognitive Sciences, vol. 11, no. 5, 2007, pp. 197-202.

23. Gaier, Ulrich. "The Problem of Core Cognition in Herder." Monatshefte, vol. 95, no. 2, 2003, pp. 294309.

24. Gall, Franz Joseph. "Des Herrn Dr. F.J. Gall Schreiben uber seinen bereits geendigten Prodromus über die Verrichtungen des Gehirns der Menschen und Thiere an Herrn Joseph Freiherr von Retzer." Der Neue Teutsche Merkur, 1798, pp. 31182.

25. Gall, Franz Joseph. Philosophisch-medicinische Untersuchungen uiber Natur und Kunst im kranken und gesunden Zustande des Menschen, Rudolph Grässer und Comp., 1791.

26. Gallese, Vittorio. "Arte, Corpo, Cervello: Per un'estetica sperimentale." Micromega, vol. 2, 2014, pp. 49-67.

27. Gallese, Vittorio. "Before and below Theory of Mind: Embodied Simulation and the Neural Correlates of Social Cognition." Philosophical Transactions of the Royal Society of London Biological Sciences, vol. 362, no. 1480, 2007, pp. 659-69.

28. Gallese, Vittorio. "Corpo non mente. Le neuroscienze cognitive e la genesi di soggettività e intersoggettività." Educazione sentimentale, vol. 20, 2013, pp. 8-24.

29. Gallese, Vittorio. "Embodied Simulation and its Role in Cognition." Reti, saperi, linguaggi, vol. 1, no. 7 , 2018, pp. 31-46.

30. Gallese, Vittorio. "Embodied Simulation: From Neurons to Phenomenal Experience." Phenomenology and the Cognitive Sciences, vol. 4, no.1, 2004, pp. 23-48.
31. Gallese, Vittorio. "Finding the Body in the Brain. From Simulation Theory to Embodied Simulation." Goldman and His Critics, edited by Brian McLaughlin and Hilary K. Kornblith, John Wiley \& Sons, 2016.

32. Gallese, Vittorio. "lo so quel che tu pensi." I/ sole 24 ore, 2006, n. 56

33. Gallese, Vittorio. "Motor Abstraction: A neuroscientific Account of how Action Goals and Intentions are mapped and understood." Psychological Research, vol. 73, 2009, pp. 486-98.

34. Gallese, Vittorio. "Naturalizing Aesthetic Experience. The Role of (Liberated) Embodied Simulation." Projections, vol. 12, no. 2, 2018, pp. 50-59.

35. Gallese, Vittorio. "The Empathic Body in Experimental Aesthetics - Embodied Simulation and Art." Empathy, Palgrave Studies in the Theory and History of Psychology, 2017.

36. Gallese, Vittorio. "The Problem of Images: A view from the Brain-Body." Phenomenology and Mind, no.14, 2018, pp. 70-79.

37. Gallese, Vittorio and Ammaniti, Massimo. La nascita della intersoggettività. Lo sviluppo del sé tra psicodinamica e neurobiologia. Cortina, 2014.

38. Gallese, Vittorio and Cuccio, Valentina. "The Paradigmatic Body. Embodied Simulation, Intersubjectivity and the Bodily Self." Open MIND, edited by Thomas Metzinger and Jennifer Windt, MIND Group, 2015, pp. 1-23.

39. Gallese, Vittorio and Guerra, Michele. Lo schermo empatico. Cinema e neuroscienze. Cortina, 2015.

40. Gallese, Vittorio and Lakoff, George. "The Brain's Concepts: the Role of the Sensory-motor System." Conceptual Knowledge. Cognitive Neuropsychology, vol. 22, n. 3/4, 2005, pp. 455-79.

41. Gallese, Vittorio and Stern, Daniel. Psychothérapie et neurosciences: une nouvelle alliance. De l'intersubjectivité aux neurones miroir. Fabert, 2015.

42. Gallese, Vittorio et al. "Action Recognition in the Premotor Cortex." Brain, vol. 119, 1996, pp. 593609.

43. Gallese, Vittorio et al. "A Unifying View of the Basis of Social Cognition." Trends in Cognitive Sciences, 2004, vol. 8, pp. 396-403.

44. Gambino, Renata and Pulvirenti, Grazia. Storie Menti Mondi. Approccio neuroermeneutico alla letteratura, Mimesis, 2018.

45. Garber, Jörn and Thoma, Heinz, editors. Zwischen Empirisierung und Konstruktionsleistung: Anthropologie im 18. Jahrhundert. Niemeyer, 2004.

46. Gehlen, Arnold. L'Uomo. La sua natura e il suo posto nel mondo, Mimesis, 2010.

47. Gjesdal, Kristin. "Herder's Hermeneutics. History, Poetry, Enlightment." Journal of the History of Philosophy, vol.56, no. 4, 2017, p. 3. 
48. Goethe, Johann Wolfgang. "Campagne in Frankreich." Goethes Werke, edited by E. Trunz, DTV, 1994, vol. 10, p. 314.

49. Häfner, Ralph. "«L'âme est une neurologie en miniature». Herder und die Neurophysiologie Charles Bonnets.". Der ganze Mensch. Anthropologie und Literatur im 18. Jahrhundert. DFG - Symposion 1992, Schings, Hans-Jurgen, Metzler, 1994, pp. 390-409.

50. Herder, Johann Gottfried. "Abhandlung über den Ursprung der Sprache." Werke in Zehn Bänden, edited by Gunter Arnold, Martin Bollacher et al, Deutscher Klassiker Verlag, 1765, vol 1, pp. 697810. For quotations from Herder's works, referring to this publication, we will use the abbreviation HW, followed by the volume number in Roman numerals and the number of pages in Arabic numerals.

51. Herder, Johann Gottfried. "Brief an Lavater nach dem 20. 2. 1775." Paralipomena, Werke in Zehn Bänden, edited by Gunter Arnold, Martin Bollacher et al, Deutscher Klassiker Verlag, 1765, vol 4, pp. 1034.

52. Herder, Johann Gottfried. "Plastik. Einige Wahrnehmungen über Form und Gestalt aus Pygmalions bildendem Traume." Werke in Zehn Bänden, edited by Gunter Arnold, Martin Bollacher et al, Deutscher Klassiker Verlag, 1765, vol. 4, pp. 244-326.

53. Herder, Johann Gottfried. "Vom Erkennen und Empfinden der menschlichen Seele." Werke in Zehn Bänden, edited by Gunter Arnold, Martin Bollacher et al, Deutscher Klassiker Verlag, 1765, vol 4.

54. Herder, Johann Gottfried. "Wie die Philosophie zum Besten des Volkes allgemein und nützlich warden kann." Werke in Zehn Bänden, edited by Gunter Arnold, Martin Bollacher et al, Deutscher Klassiker Verlag, 1765, vol. 1, p. 122.

55. Herder, Johann Gottfried. Zum Sinn des Gefüh/s (1769), in Werke in Zehn Bänden, edited by Gunter Arnold, Martin Bollacher et al, Deutscher Klassiker Verlag, IV, 235-242.

56. Husserl, Edmond. Idee per una fenomenologia pura e per una filosofia fenomenologica. Vol. 3: La fenomenologia e i fondamenti delle scienze, Einaudi, 1976-1982.

57. Husserl, Edmond. Meditazioni cartesiane e Lezioni parigine. Editrice La Scuola, 2017.

58. Hustvedt, Siri, Gallese, Vittorio et al. Fühlen Denken - Erinnern: Schreiben zwischen Wissenschaft und Poesie: Tübinger Poetik Dozentur 2016. Swiridoff Verlag, 2017.

59. Iacoboni, Marco. "Existential Empathy: the Intimacy of Self and Other." Empathy in Mental IIIness, edited by T.F.D. Farrow and Peter Woodruff, Cambridge UP, 2007, pp. 310-321.
60. Iacoboni, Marco et al. "Grasping the intentions of others with one's own mirror neuron system." Plos Biology, 2005, vol. 3.

61. Irmscher, Hans Dietrich. "Bemerkungen zur Funktion der Analogie im Denken Herders." Deutsche Vierteljahrschrift für Literaturwissenschaft und Geistesgeschichte, 1981, vol. 55.

62. Irmscher, Hans Dietrich, Johann Gottfried Herder. Reclam, 2001.

63. Johnson, Mark and Rohrer, Tim. "We are Live Creatures: Embodiment, American Pragmatism, and the Cognitive Organism." Body, Language, and Mind, 2007, vol. 1, pp. 17-54.

64. Kant, Immanuel. "Kritik der reinen Vernunft.", Kant's Gesammelte Schriften, edited by Berlin Academy of Sciences, de Gruyter, Berlin 1910-1983, vol. 3, pp. $1-152$.

65. Koschorke, Albrecht. Körperströme und Schriftverkehr. Mediologie des 18. Jahrhunderts. Fink,1999.

66. Košenina, Alexander. Ernst Platners Anthropologie und Philosophie. Der philosophische Arzt und seine Wirkung auf Johann Karl Wezel und Jean Paul. Königshausen \& Neumann, 1989.

67. Lange, Thomas and Neumeyer, Harald, editors. Kunst und Wissenschaft um 1800. Königshausen und Neumann, 2000.

68. Lakoff, George and Johnson, Mark. Metaphors We Live By. Chicago UP 1980.

69. Lakoff, George and Johnson, Mark. Philosophy in the Flesh. Basic Books, 1999.

70. Lesky, Erna, editor. Franz Joseph Gall 1758-1828. Naturforscher und Anthropologe. Huber, 1979.

71. Lesky, Erna, "Gall und Herder." Clio Medica, 1967, vol.2.

72. Löchte, Anne. Johann Gottfried Herder: Kulturtheorie und Humanitätsidee der Ideen, Humanitätsbriefe und Adrastea. Königshausen \& Neumann, 2005.

73. Marelli, Francesco. Fisica dell'anima. Estetica e antropologia in J.G. Herder. Mimesis, 2012, p. 13.

74. Marino, Mario. Da Gehlen a Herder, origine del linguaggio e ricezione di Herder nel pensiero antropologico Tedesco. II Mulino, 2008, p. 104.

75. Maturana, Humberto and Varela, Francisco. Autopoiesis and Cognition: The Realization of the Living. Reidel Publishing, 1980.

76. Maturana, Humberto and Varela, Francisco. Autopoiesi e cognizione. La realizzazione del vivente, Marsilio, 1985.

77. Maturana, Humberto and Varela, Francisco. L'albero della conoscenza. Garzanti, 1987.

78. Meyer, Anna-Rose. Homo dolorosus. Körper Schmerz - Ästhetik, Fink, 2011.

79. Müller, Johann, Georg, editor. Erinnerungen aus dem Leben Joh. Gottfrieds von Herder, Sämtliche Werke, edited by K.Fr.A. Schelling and J.G. Cotta, 1856-1861, vol. 12, no. 109. 
80. Newen, Albert, De Bruin, Leon and Gallagher, Shaun, editors. The Oxford Handbook of $4 E$ Cognition. OUP, 2018.

81. Noë, Alva, "Vision without Representation." Perception, Action, and Consciousness: Sensorimotor Dynamics and Two Visual Systems, edited by Nivedita Gangopadhyay, Michael Madary and Finn Spicer, Oxford University Press, 2010.

82. Offray de La Mettrie, Julien. L'Homme Machine. Elie Luzac Fils, 1747.

83. Pace, Alessandra, Gallese Vittorio et al. Mirror Images: Spiegelbilder in Kunst und Medizin / Reflections in Art and Medicine. Verlag für Moderne Kunst, 2017.

84. Platner, Ernst. Anthropologie für Ärzte und Weltweise. Erster Teil. Dyc, 1772.

85. Rizzolatti, Giacomo et al. "Functional Organization of Inferior Area 6 in the Macaque Monkey. II. Area F5 and the Control of Distal Movements." Experimental Brain Research, 1988, vol. 71, no. 3, pp. 491-507.

86. Rizzolatti, Giacomo et al. "Motor and Cognitive Functions on the Ventral Premotor Cortex." Current Opinion in Neurobiology, 2002, vol. 12, pp. 149-54.

87. Rizzolatti, Giacomo et al. "Neurophysiological Mechanisms underlying the Understanding and Imitation of Action." Nature Reviews Neuroscience, 2001, vol. 2, pp. 661-70.

88. Rizzolatti, Giacomo et al. "Premotor Cortex and the Recognition of Motor Actions." Cognitive Brain Research, 1996, vol. 3, pp. 131-141.

89. Rizzolatti, Giacomo and Sinigaglia, Corrado. So quel che fai. II cervello che agisce e i neuroni specchio. Raffaello Cortina, 2006, p. 4.

90. Rizzolatti, Giacomo and Sinigaglia, Corrado. "The Functional Role of the Parieto-frontal Mirror Circuit: Interpretations and Misinterpretations." Nature Reviews Neuroscience, 2010, vol. 11, no. 4, pp. 264-74.

91. Rothschuh, Karl. "Naturphilosophische Konzepte der Medizin aus der Zeit der deutschen Romantik." Romantik in Deutschland, edited by R. Brinkmann, Metzler, 1978, pp. 243-267.

92. Roughley, Neil. Being Humans: Anthropological Universality and Particularity in Transdisciplinary Perspectives. De Gruyter, New York, 2012.

93. Sauder, Gerhard. "Sinnliche Erkenntnis: Der Kontext von Herders 'Abhandlung Vom Erkennen und Empfinden der menschlichen Seele'." Herder: From Cognition to Cultural Science edited by Beate Allert, Synchron, 2016, pp. 137-53.

94. Sauder, Gerhard. Empfindsamkeit. Voraussetzungen und Elemente. Metzler, 1974.

95. Schelling, Friedrich Wilhelm Joseph. "Ideen zu einer Philosophie der Natur." Werke. Historisch-kritische Ausgabe, edited by Baumgartner et al., FrommannHolzboog, 1975, vol. 5, p. 107.
96. Schelling, Friedrich Wilhelm Joseph "Von der Weltseele. Eine Hypothese der höheren Physik zur Erklärung des allgemeinen Organismus." Sämtliche Werke, edited by K.Fr.A. Schelling and J.G. Cotta, 1856-1861, vol. 2.

97. Schings, Hans-Jurgen. Der ganze Mensch. Anthropologie und Literatur im 18. Jahrhundert. DFG - Symposion 1992. Metzler, 1994, p. 1.

98. Simon, Ralf. "Goethes Denken in Analogien. Zur literarischen Epistemologie der Ähnlichkeiten als Horizontalisierung der Reflektion." Ähnlichkeit um 1800. Konturen eines literatur- und kulturtheoretischen Paradigmas am Beginn der Moderne, edited by J.-K. Patrutt, R. Rössler, Aisthesis Verlag, 2019.

99. Sohni, Hans. Die Medizin der Frühromantik. Schulz Verlag, 1973.

100. Stöckmann, Ernst. Anthropologische Ästhetik. Philosophie, Psychologie und ästhetische Theorie der Emotionen im Diskurs der Aufklärung. Niemeyer, 2009.

101. Thelen, Ester et al. "Empathy and Consciousness." Journal of Consciousness Studies, 2001, vol. 8.

102. Thelen, Ester et al. "The Dynamics of Embodiment." Behavioral and Brain Sciences, 2001, vol. 24, pp. 1-86.

103. Thompson, Evan. Mind in Life. Biology, Phenomenology and the Science of Mind. Harvard UP, 2010.

104. Thompson, Evan. "Empathy and Consciousness". Journal of Consciousness, vol. 8, 2001, pp. 5-7.

105. Umiltà, Maria Alessandra et al. "I know what you are doing. A neurophysiological study." Neuron, 2001, vol. 31, no. 1, pp. 156-65

106. Varela, Francisco, Thompson, Evan, Rosch Eleanor, editors, The Embodied Mind. Cognitive Science and Human Experience, MIT Press, 1991.

107. Verra, Valerio. "Die Vergleichungsmethode bei Herder und Goethe." Bausteine zu einem neuen Goethe, edited by P. Chiarini, Athenäum, 1987.

108. Vila, Anne. "The Sensible Body: Medicine and Literature in Eighteenth-Century France." Diss., University Microfilms Internat., 1990.

109. Von Haller, Albrcht. Primae lineae physiologiae in usum praelectionum academicarum auctae et emendatae, 1751.

110. Von Hardenberg, Friedrich. Die Werke Friedrich von Hardenbergs. Wissenschaftliche Buchgesellschaft, 1960-2006, vol. 4.

111. Waldow, Anik and Nigel DeSouza. Herder: Philosophy and Anthropology. Oxford University Press, 2017.

112. Weiler, Christina. "The Romantic Roots of Cognitive Poetics: A Comparative Study of Poetic Metaphor in Herder, Novalis, Wordsworth, Coleridge, and Shelley." Diss. Purdue U, 2017. 
113. Wojciehowski, Hannah and Gallese, Vittorio. "Introduction. Narrative and the Biocultural Turn." Costellazioni. Rivista di Lingue e letterature, vol. 5, 2018, pp. 9-21.

114. Zahavi, Dan. Husserl and Transcendental Intersubjectivity: A Response to the LinguisticPragmatic critique, Ohio University Press, 2001.

115. Zelle, Carsten. "Commercium mentis et corporis. La contribution de Johann Gottlob Krüger à l'anthropologie littéraire autour de 1750." Revue Germanique Internationale, vol. 10, 2009, pp. 11-29.

116. Zelle, Carsten, editor. «Vernünftige Ärzte». Hallesche Psychomediziner und die Anfänge der Anthropologie in der deutschsprachigen Frühaufklärung. Niemeyer, 2001.

117. Zelle, Carsten. "Zur Idee des "ganzen Menschen« im 18. Jahrhundert." Beiträge zum II Internationalen Kongress für Pietismusforschung. Verlag der Frankeschen Stiftungen im Max Niemeyer, 2009, pp. 45-61. 